\title{
EFEKTIVITAS PEMBERIAN AROMATERAPI LAVENDER DAN JAHE TERHADAP PENURUNAN FREKUENSI MUAL MUNTAH PADA IBU HAMIL TRIMESTER I DI BPM TRUCUK KLATEN
}

\author{
RD. Rahayu, Sugita \\ Kementerian Kesehatan Politeknik Kesehatan Surakarta Jurusan Kebidanan
}

\begin{abstract}
Lavender Aromtherapy, Ginger Aromatherapy, Nausea Vomiting, Pregnant Mother. Aromatherapy is a therapy modality or alternative treatment by using a pure aromatherapy extract in the form of volatile plant fluid material and other aromatherapy compounds from plants. Knowing the Effectiveness of Aromatherapy Lavender and Ginger Aromatherapy on Reduced Frequency of Nausea Vomiting in Trimester Pregnant Mother at BPM Trucuk Klaten. Quantitative type with this research design using quasi experiment (quasi experiment). The population in this study were all trimester I pregnant mother who checked their pregnancy at BPM Trucuk Klaten during may until Juni 2017. The sampling technique is accidental sampling is 32 pregnan. Data analysis using paired t-test and independent t-test.Results. There was a significant difference between mean intensity degree of vomiting before and after ginger aroma therapy with $p$ value $=0,000(\alpha<0,05)$. There was a significant difference between mean intensity of degree of nausea of vomiting before and after aromatherapy therapy with $p$ value $0.000(\alpha<0,05)$. The scent of lavender therapy is more effective against nausea and vomiting (8.50) than in the ginger aroma therapy group (6.50), so it can be concluded that the aroma of lavender therapy is more effective than the aroma of ginger therapy.
\end{abstract}

Keywords: Lavender Aromtherapy, Ginger Aromatherapy, Nausea Vomiting, Pregnant Mother

Abstrak : Aromaterapi Lavender, Aromaterapi Jahe, Mual Muntah, Ibu Hamil. Aromaterapi merupakan terapi modalitas atau pengobatan alternative dengan menggunakan sari tumbuhan aromaterapi murni berupa bahan cairan tanaman yang mudah menguap dan senyawa aroma terapi lain dari tumbuhan. Mengetahui Efektivitas Pemberian Aromaterapi Lavender dan Jahe terhadap Penurunan Frekuensi Mual Muntah pada Ibu Hamil Trimester I di BPM Trucuk KlatenMetode.Jenis kuantitatif dengan desain penelitian ini menggunakan eksperimen semu (quasi eksperimen). Populasi dalam penelitian ini adalah semua ibu hamil trimester I yang memeriksakan kehamilannya di BPM Trucuk Kabupaten Klaten pada bulan Mei sampai Juni 2017. Teknik sampling adalah accidental sampling sebanyak $32 \mathrm{ibu}$ hamil. Analisa data menggunakan paired t-test dan independent t-test. Hasil.Karakteristik responden sebagian besar adalah umur 20-35 tahun (71,9\%), pendidikan SMP (53,1\%), suku bangsa seluruh responden bersuku bangsa Jawa (100\%), pekerjaan ibu adalah tidak bekerja atau ibu rumah tangga $(81,3 \%)$. Karakteristik mual muntah kurang dari 1 jam sebanyak (100\%) dan banyaknya 1-2 cangkir (100\%). Ada perbedaan yang signifikan antara mean intensitas derajat mual muntah sebelum dan sesudah pemberian aroma 
terapi jahe dengan nilai $\mathrm{p}$ value $=0,000(\alpha<0,05)$. Ada perbedaan yang signifikan antara mean intensitas derajat mual muntah sebelum dan setelah pemberian aroma terapi lavender denga nilai $\mathrm{p}$ value $+0,000(\alpha<0,05)$.Kesimpulan. Aroma terapi lavender lebih efektif terhadap mual muntah $(8,50)$ dibandingkan dengan kelompok aroma terapi jahe $(6,50)$, sehingga dapat disimpulkan bahwa pemberian aroma terapi lavender lebih efektif dibandingkan aroma terapi jahe.

Kata Kunci : Aromaterapi Lavender, Aromaterapi Jahe, Mual Muntah, Ibu Hamil

\section{PENDAHULUAN}

Mual dan muntah terjadi pada 60$80 \%$ primigravida dan $40-60 \%$ multigravida. Seratus dari seribu kehamilan, gejala ini menjadi lebih berat. Perasaan mual ini disebabkan oleh karena meningkatnya kadar hormon estrogen dan hCG dalam serum. Pengaruh fisiologik kenaikan hormon ini belum jelas, mungkin karena sistem saraf pusat atau pengosongan lambung yang berkurang, sehingga menyebabkan mual muntah pada ibu hamil (Santi, 2013).

Mual dan muntah pada ibu hamil trimester pertama di masyarakat masih terjadi dan cara penanggulangannya sebagian besar masih menggunakan terapi farmakologis. Penatalaksanaan mual dan muntah pada kehamilan tergantung pada beratnya gejala. Pengobatan dapat dilakukan dengan cara farmakologi maupun nonfarmakologi. Terapi farmakologi dilakukan dengan pemberian antiemetik, antihistamin, antikolinergik, dan kortikosteroid, namun ibu hamil akan lebih baik jika mampu mengatasi masalah mual pada awal kehamilan dengan menggunakan terapi pelengkap nonfarmakologis. Terapi nonfarmakologis bersifat noninstruktif, noninfasif, murah, sederhana, efektif, dan tanpa efek samping yang merugikan. Terapi nonfarmakologi dapat dilakukan dengan cara pengaturan diet, dukungan emosional, akupuntur, dan pemberian aromaterapi (Wiknjosastro, 2010).

Aromaterapi merupakan terapi modalitas atau pengobatan alternative dengan menggunakan sari tumbuhan aromaterapi murni berupa bahan cairan tanaman yang mudah menguap dan senyawa aroma terapi lain dari tumbuhan (Kushariyadi, 2011). Aromaterapi memberikan ragam efek bagi penghirupnya, seperti ketenangan, kesegaran, bahkan bisa membantu ibu hamil mengatasi mual. Aromaterapi dapat digunakan sebagai solusi untuk mengatasi mual muntah pada ibu hamil trimester pertama.

Jahe sebagai salah satu jenis tanaman herbal mempunyai banyak keunggulan dibandingkan dengan tanaman herbal lainya, khususnya bagi ibu hamil yang sedang mengalami mual muntah. Keunggulan pertama jahe adalah kandungan mengandung minyak terbang (minyak atsiri) yang menyegarkan dan memblokir reflek muntah sedang gingerol sehingga dapat melancarkan peredaran darah dan syaraf-syaraf bekerja dengan baik. Hasilnya, ketegangan bisa dicairkan, kepala jadi segar, mual muntah pun bisa ditekan. Aroma harum jahe disebabkan oleh minyak atsiri, sedangkan olesannya menyebabkan rasa pedas yang menghangatkan tubuh dan mengeluarkan keringat (Nikita, 2011). 
Data dari Dinas Kesehatan tentang rekapitulasi laporan bulanan data kesakitan Puskesmas se-Kabupaten Klaten pada penyakit hiperemesis tahun 2015 berjumlah 406 jiwa, tahun 2016 berjumlah 547 jiwa dan tahun 2017 sampai Bulan Februari berjumlah 96 jiwa. Data dari Puskesmas Trucuk Klaten tentang hiperemesis tahun 2016 berjumlah 32 kasus dari 598 sasaran ibu hamil. Data tentang keluhan-keluhan yang dialami oleh ibu hamil trimester 1 di Puskesmas Kecamatan Trucuk Klaten tahun 2016 didapatkan 26 orang mengeluhkan mual $(58,14 \%)$.

Hasil survey pendahuluan yang dilakukan pada bulan akhir Februari 2017 di BPM Trucuk Klaten pada 5 ibu hamil trimester I yang melakukan pemeriksaan kehamilan didapatkan data bahwa sebanyak 4 orang $(80 \%)$ mengalami mual muntah dan satu orang (20\%) tidak mengalami mual muntah. Data hasil wawancara pada $10 \mathrm{ibu}$ hamil yang mengalami mual muntah didapatkan sebanyak 8 ibu hamil telah melakukan penanganan mual muntah menggunakan aroma terapi yaitu minyak kayu putih dan 2 ibu hamil mengatakan tidak menggunakan aroma terapi.

Berdasarkan data maka peneliti tertarik untuk meneliti tentang "Efektivitas Pemberian Aromaterapi Lavender dan Jahe terhadap Penurunan Frekuensi Mual Muntah pada Ibu Hamil Trimester I di BPM Trucuk Klaten"

Penelitian ini bertujuan untuk mengetahui Efektivitas Pemberian Aromaterapi Lavender dan Jahe terhadap Penurunan Frekuensi Mual Muntah pada Ibu Hamil Trimester I di BPM Trucuk Klaten

\section{METODE PENELITIAN}

Penelitian ini berjenis kuantitatif dengan desain penelitian ini menggunakan eksperimen semu (quasi eksperimen). Populasi dalam penelitian ini adalah semua ibu hamil trimester I yang memeriksakan kehamilannya di BPM Trucuk Klaten.Teknik sampling yang digunakan quota sampling. Analisis data telah terdistribusi normal melalui uji normalitas data menggunakan Shapirowilk. Analisis data jika data normal maka digunakan uji wilcoxon.

\section{HASIL PENELITIAN}

1. Karakteristik Responden

Tabel 1

Distribusi Frekuensi Karakteristik

Responden Berdasarkan Umur, Suku, pendidikan dan Pekerjaan di BPM Trucuk Klaten

\begin{tabular}{|c|c|c|c|c|c|c|c|}
\hline \multirow[t]{3}{*}{ No } & \multirow[t]{3}{*}{ Karakteristik } & \multicolumn{4}{|c|}{ Aroma terapi } & \multirow{2}{*}{\multicolumn{2}{|c|}{ Jumlah }} \\
\hline & & \multicolumn{2}{|c|}{ Jahe } & \multicolumn{2}{|c|}{ Lavender } & & \\
\hline & & $\mathbf{F}$ & $\%$ & f & $\%$ & f & $\%$ \\
\hline \multirow[t]{4}{*}{1} & Umur & & & & & & \\
\hline & $<20$ tahun & 0 & 0 & 0 & 0 & 0 & 0 \\
\hline & 20-35 tahun & 12 & 37,5 & 11 & 34,4 & 23 & 71,9 \\
\hline & $>35$ tahun & 4 & 12,5 & 5 & 15,6 & 9 & 28,1 \\
\hline \multirow[t]{3}{*}{2} & Suku & & & & & & \\
\hline & Jawa & 16 & 50 & 16 & 50 & 32 & 100 \\
\hline & Non Jawa & 0 & 0 & 0 & 0 & 0 & 0 \\
\hline \multirow[t]{4}{*}{3} & Pendidikan & & & & & & \\
\hline & SD & 0 & 0 & 0 & 0 & 0 & 0 \\
\hline & SMP & 8 & 25 & 9 & 28,1 & 17 & 53,1 \\
\hline & SMA & 8 & 25 & 7 & 21,9 & 15 & 46,9 \\
\hline \multirow[t]{3}{*}{4} & Pekerjaan & & & & & & \\
\hline & Tidak Bekerja & 14 & 43,8 & 13 & 37,5 & 27 & 89,4 \\
\hline & Bekerja & 2 & 6,3 & 3 & 9,4 & 5 & 15,6 \\
\hline
\end{tabular}

menunjukkan bahwa dari 32 responden yang diteliti, mayoritas distribusi responden menurut usia ialah kelompok usia 20-35 tahun dengan jumlah 23 orang responden $(71,9 \%)$, suku ibu hamil adalah suku Jawa dengan jumlah 32 responden (100\%), pendidikan terakhir ibu sebagian besar ialah SMP dengan jumlah 17 responden $(53,1 \%)$, responden sebagian 
besar adalah ibu rumah tangga sebanyak 26 responden $(81,3 \%)$.

\section{Tabel 2}

Distribusi Frekuensi Karakteristik Responden Berdasarkan Lamanya dan Banyaknya Mual Muntah di BPM Trucuk Klaten

\begin{tabular}{|c|c|c|c|c|c|c|c|}
\hline \multirow{3}{*}{ No } & \multirow{3}{*}{$\begin{array}{c}\text { Karakteristi } \\
\mathbf{k}\end{array}$} & \multicolumn{4}{|c|}{ Aroma terapi } & \multirow{2}{*}{\multicolumn{2}{|c|}{ Jumlah }} \\
\hline & & \multicolumn{2}{|c|}{ Jahe } & \multicolumn{2}{|c|}{ Lavender } & & \\
\hline & & f & $\%$ & f & $\%$ & $\mathbf{F}$ & $\%$ \\
\hline 1 & Lamanya & & & & & & \\
\hline \multirow{5}{*}{2} & $<1$ jam & 0 & 0 & 0 & 0 & 0 & 0 \\
\hline & $\geq 1$ jam & 16 & 50 & 16 & 50 & 32 & 100 \\
\hline & Banyaknya & & & & & & \\
\hline & 1-2 cangkir & 16 & 50 & 16 & 50 & 32 & 100 \\
\hline & 1 cangkir & 0 & 0 & 0 & 0 & 0 & 0 \\
\hline
\end{tabular}

Berdasarkan tabel 2 lamanya mual muntah kurang dari 1 jam dan banyaknya mual muntah sebanyak 1-2 cangkir.

2. Kejadian Mual Muntah pada Aromatherapi Lavender dan Jahe

Tabel 3

Distribusi Frekuensi Mual Muntah pada Aromatherapi Lavender Hari 1-4 di BPM Trucuk Klaten

\begin{tabular}{|c|c|c|c|}
\hline No & Mual-Muntah & Frekuensi & $\%$ \\
\hline \multirow[t]{6}{*}{1} & Hari 1 & & \\
\hline & Skala 1 & 2 & 12,5 \\
\hline & Skala 2 & 3 & 18,8 \\
\hline & Skala 3 & 6 & 37,5 \\
\hline & Skala 4 & 2 & 12,5 \\
\hline & Skala 5 & 3 & 18,8 \\
\hline \multirow[t]{4}{*}{2} & Hari 2 & & \\
\hline & Skala 1 & 5 & 31,2 \\
\hline & Skala 2 & 3 & 18,8 \\
\hline & Skala 3 & 8 & 50,0 \\
\hline \multirow[t]{5}{*}{3} & Hari 3 & & \\
\hline & Skala 0 & 1 & 6,2 \\
\hline & Skala 1 & 11 & 68,8 \\
\hline & Skala 2 & 3 & 18,8 \\
\hline & Skala 3 & 1 & 6,2 \\
\hline \multirow[t]{4}{*}{4} & Hari 4 & & \\
\hline & Skala 0 & 4 & 25 \\
\hline & Skala 1 & 12 & 75 \\
\hline & Jumlah & 16 & 100 \\
\hline
\end{tabular}

bahwa pada hari 1 ibu mengalami mual muntah paling banyak 3 kali yaitu 6 orang
$(37,5 \%)$, hari kedua 3 kali yaitu 8 orang (50\%), hari ke 3 paling banyak 1 kali sebanyak 11 orang $(68,8 \%)$ dan hari ke 4 paling anyak 1 kali sebanyak 12 orang $(75 \%)$.

Tabel 4

Distribusi Frekuensi Mual Muntah pada Aromatherapi Jahe Hari 1-4 di BPM Trucuk Klaten

\begin{tabular}{clcc}
\hline No & Mual-Muntah & Frekuensi & \% \\
\hline 1 & Hari 1 & & \\
& Skala 1 & 3 & 18,8 \\
& Skala 2 & 0 & 0 \\
& Skala 3 & 6 & 37,5 \\
& Skala 4 & 5 & 31,2 \\
& Skala 5 & 2 & 12,5 \\
& Hari 2 & & \\
& Skala 1 & 5 & 31,2 \\
& Skala 2 & 2 & 12,5 \\
& Skala 3 & 9 & 54,3 \\
& Hari 3 & & \\
& Skala 0 & 1 & 6,2 \\
& Skala 1 & 11 & 68,8 \\
& Skala 2 & 3 & 18,8 \\
& Skala 3 & 1 & 6,2 \\
4 & Hari 4 & & \\
& Skala 0 & 2 & 12,5 \\
& Skala 1 & 14 & 87,5 \\
\hline \multirow{4}{*}{ Jumlah } & 16 & 100 \\
\hline \multirow{2}{*}{} & Berdasarkan & tabel & diketahui
\end{tabular}
bahwa pada hari 1 ibu mengalami mual muntah paling banyak 3 kali yaitu 6 orang (37,5\%), hari kedua 3 kali yaitu 9 orang (54,3\%), hari ke 3 paling banyak 1 kali sebanyak 11 orang $(68,8 \%)$ dan hari ke 4 paling banyak 1 kali sebanyak 14 orang $(87,5 \%)$.

3. Mual Muntah Ibu Hamil

Tabel 5

Distribusi Intensitas Mual Muntah pada Ibu Hamil Trimester I Sebelum Diberikan Aroma Terapi Lavender dan

\begin{tabular}{lllll}
\multicolumn{5}{c}{ Jahe } \\
\hline \multirow{2}{*}{ Kelompok } & \multirow{2}{*}{$\mathrm{N}$} & Pretest & & \\
\cline { 3 - 5 } & & Median & Min & Maks \\
\hline Lavender & 16 & 4,00 & 3,00 & 5,00 \\
Jahe & 16 & 3,00 & 2,00 & 5,00 \\
\hline
\end{tabular}


Berdasarkan tabel 5 nilai median pada kelompok jahe pada titik 3,00 sedangkan milai median kelompok aroma terapi lavender pada titik 4,00.

\section{Tabel 6}

Perbedaan Intensitas Mual Muntah Sebelum dan Sesudah Pemberian Aromaterapi Jahe

\begin{tabular}{|c|c|c|c|c|c|c|}
\hline $\begin{array}{l}\text { Kelompok } \\
\text { Jahe }\end{array}$ & $\mathrm{N}$ & Mean & $\begin{array}{l}\text { Mean } \\
\text { Perubahan }\end{array}$ & SD & SE & $\begin{array}{l}\mathrm{P} \\
\text { value }\end{array}$ \\
\hline Pretest & 16 & 3,93 & 1,875 & 0,771 & 0,192 & 0,00 \\
\hline Postest & 16 & 2,06 & & 1,388 & 0,347 & \\
\hline
\end{tabular}

Dari tabel 6 didapatkan bahwa nilai rata-rata intensitas mual muntah sebelum diberikan aroma terapi jahe adalah 3,93 dengan standar deviasi 1,388. Perbedaan nilai pretest dan postest pada kelompok aroma terapi jahe adalah 1,875. Hasil analisa diperoleh $\mathrm{p}(0,000)<\alpha$ $(0,05)$, maka dapat disimpulkan ada perbedaan yang signifikan antara mean intensitas derajat mual muntah sebelum dan sesudah pemberian aroma terapi jahe.

Tabel 7

\section{Perbedaan Intensitas Mual Muntah Sebelum dan Sesudah Pemberian Aroma Terapi Lavender}

\begin{tabular}{lllllll}
\hline $\begin{array}{l}\text { Kelompok } \\
\text { Lavender }\end{array}$ & N & Mean & $\begin{array}{l}\text { Mean } \\
\text { Perubahan }\end{array}$ & SD & SE & $\begin{array}{l}\text { P } \\
\text { value }\end{array}$ \\
\hline Pretest & 16 & 3,31 & 2,437 & 0,873 & 0,218 & 0,000 \\
Postest & 16 & 0,87 & & 0,885 & 0,221 & \\
\hline
\end{tabular}

Berdasarkan tabel 7, didapatkan nilai rata-rata intensitas derajat mual muntah ibu hamil sebelum diberikan aroma terapi lavender adalah 3,31 dengan standar deviasi 0,873 dan 0,87 rata-rata intensitas mual muntah sesudah pemberian aroma terapi lavender dengan standar deviasi 0,885. Perbedaan nilai mean pretest dan postest pada kelompok aroma terapi lavender adalah sebesar 2,347 . Hasil analisa diperoleh $\mathrm{p}=0,000<$ $\alpha(0,05)$, maka dapat disimpulkan ada perbedaan yang signifikan antara mean intensitas derajat mual muntah sebelum dan setelah pemberian aroma terapi lavender.

\section{Tabel 8}

Perbandingan Intensitas Mual Muntah Sesudah (protest) dan Pemberian Aroma Terapi Jahe dan Lavender

\begin{tabular}{|c|c|c|c|c|c|c|c|}
\hline \multirow{2}{*}{ Kelompok } & \multirow{2}{*}{$\mathrm{N}$} & \multicolumn{2}{|c|}{ Pretest } & \multicolumn{2}{|c|}{ Postest } & \multirow{2}{*}{$\begin{array}{l}\text { Mean } \\
\text { Rank }\end{array}$} & \multirow{2}{*}{$\begin{array}{l}\mathrm{P} \\
\text { value }\end{array}$} \\
\hline & & Mean & SD & Mean & SD & & \\
\hline Jahe & 16 & 3,00 & 1,45 & 2,06 & 1,38 & 6,50 & 0,002 \\
\hline Lavender & 16 & 2,09 & 1,51 & 0,87 & 0,88 & 8,50 & 0,000 \\
\hline
\end{tabular}

memperlihatkan rata-rata intensitas derajat mual muntah pada ibu hamil sesudah diberikan aroma terapi jahe adalah 2,06 dengan standar deviasi 1,38 dan 0,87 nilai rata-rata intensitas mual dan muntah sesudah diberikan aroma terapi lavender dengan standar deviasi 0,88 , hasil analisa diperoleh pada kelompok pemberian aroma terapi jahe diperoleh $\mathrm{p}$ value $(0,002)<\alpha(0,05)$ dapat disimpulkan terdapat perbedaan yang signifikan setelah pemberian aroma terapi jahe, sedangkan pada kelompok aroma terapi lavender $\mathrm{p}$ value $(0,000)<\alpha(0,05)$ dengan kesimpulan ada perbedaan yang signifikan sesudah pemberian aroma terapi lavender. Hasil mean rank pretest dan postest untuk kedua kelompok eksperimen, didapatkan hasil aroma terapi lavender lebih efektif terhadap mual muntah $(8,50)$ dibandingkan dengan kelompok aroma terapi jahe (6,50), sehingga dapat disimpulkan bahwa pemberian aroma terapi lavender lebih efektif dibandingkan aroma terapi jahe.

\section{PEMBAHASAN}

Berdasarkan hasil penelitian yang dilakukan di BPM Trucuk Klaten didapatkan hasil usia responden terbanyak berada pada rentang umur 20-35 tahun yang mengalami mual muntah dengan 
kehamilan primigravida. Hasil penelitian ini sesuai dengan penelitian yang telah dilakukan oleh Razak (2010) tentang hubungan umur ibu dengan kejadian hyperemesis gravidarum dengan hasil penelitian terdapat hubungan yang bermakna antara umur dengan kejadian hypoeremesis gravidarum dimana umur ibu hamil dengan risiko tinggi $(<20$ tahun dan $>35$ tahun) sedangkan umur dengan kejadian hyperemesis gravidarum dimana umure ibu hamil dengan risiko rendah (20-35 tahun).

Hasil penelitian ini juga sesuai dengan penelitian yang dilakukan Rimonta (2010) tentang perbandingan efektivitas kombinasi ekstrak jahe dan piridoksin dengan piridoksin saja dalam mengurangi keluhan mual dan muntah pada wanita hamil, dengan hasil ibu hamil usia 16 tahun, > 35 tahun, dan dengan kehamilan primigravida cenderung mengalami mual muntah dengan skala berat dibandingkan pada kehamilan multigravida, karena usia dibawah 20 tahun belum cukup siap dalam hal kematangan fisik dan mental dna fungsi sosial dari calon ibu yang dapat mempengaruhi emosi ibu, sehingga terjadi konflik mental yang membuat ibu kurang nafsu makan. Bila ini terjadi dapat menyebabkan iritasi lambung sehingga terjadi mual muntah.

Suku responden semuanya ialah suku Jawa sebanyak (100\%). Hasil ini sesuai dengan penelitian Robert dan Pepper (2010) bahwa suku terbanyak adalah Jawa. Penelitian ini didukung dengan penelitian Liputo (2010), bahwa pada suku Jawa, bahan utama untuk sebagian besar jenis masakannya adalah karbohidrat yang juga mengandung lemak dengan nilai asam lemak jenuh, sehingga ibu hamil yang berasal dari suku Jawa memiliki risiko lebih besar untuk mengalami kejadian mual muntah; karena makanan yang bersantan dan bumbu yang menyengat dapat merangsang ibu hamil untuk mual muntah. Hasil penelitian ini sesuai dengan data dari Badan Pusat Statistik Provinsi Jawa Tengah (2010) yang menyatakan bahwa suku Jawa adalah salah satu suku bangsa yang banyak berdomisili di provinsi Jawa Tengah khususnya wilayah Klaten.

Pendidikan terakhir ibu sebagian besar adalah SMP. Hasil penelitian ini sesuai dengan Rimonta (2010), bahwa pendidikan mempunyai pengaruh yang lebih tinggi terhadap kejadian mual muntah dalam kehamilan. Hasil peneliti ini sesuai dengan penelitian yang dilakukan Henny (2012) tentang hubungan antara status gravida dengan kejadian emesis gravidarum pada ibu hamil trimester I yang menyimpulkan pendidikan sangat berpengaruh terhadap gejala mual muntah karena kurangnya informasi tentang kehamilan terutama pada primigravida trimester I. Hal ini disebabkan karena ilmu pengetahuan selalu kurang berkembang seiring dengan kemajuan zaman,

Informasi dapat diperoleh dari berbagai sumber seperti dari buku bacaan, koran, televisi, radio, internet, berdiskusi dengan penolong persalinan atau dengan siapapun yang mengerti seputar kehamilan dan persalinan. Pengetahuan dan informasi yang didapat oleh ibu sehingga apabila primigravida mengalami emesis gravidarum dapat segera mengatasinya agar tidak berlnajut menjadi hiperemesis gravidarum. Rahmawati (2010) tentang hubungan antara paritas, umur, pendidikan dengan kejadian emesis gravidarum, dengan hasil pendidikan dapat mempengaruhi seseorang termasuk juga 
perilaku terhadap pola hidup dalam memotivasi untuk siap berperan serta dalam perubahan kesehatan. Hal ini dikarenakan rendahnya pendidikan seseorang makin sedikit keinginan untuk memanfaatkan pelayanan kesehatan dan sebaliknya makin tingginya pendidikan seseorang, makin mudah untuk menerima informasi dan memanfaatkan pelayanan kesehatan yang ada.

Berdasarkan uji statistik dengan menggunakan uji wilcoxon diperoleh nilai $p$ value $(0,002)<\alpha(0,005)$. Hal ini berarti terdapat perbedaan yang signifikan antara rata-rata intensitas derajat mual muntah sebelum dan sesudah diberikan aroma terapi jahe, sedangkan rata-rata intensitas derajat mual muntah ibu hamil sebelum dan sesudah diberikan aroma terapi lavender diperoleh $\mathrm{p}$ value $(0,000)<\alpha$ $(0,05)$. Hasil tersebut menunjukkan terdapat perbedaan signifikan antara ratarata intensitas derajat mual muntah sebelum dan sesudah diberikan aroma terapi lavender dan jahe pada ibu hamil.

Hasil penelitian ini sesuai dengan Pramote (2010) bahwa jahe efektif untuk mengurangi derita mual muntah selama hamil, karena penggunaan aroma terapi untuk mengatasi mual dan muntah tidak akan meningkatkan risiko negatif pada janin serta penggunaan jahe sudah dipakai sebagai obat anti muntah dan agen anti pembawa penyakit. Smith (2010), mengatakan terapi alternatif yang biasa digunakan dalam mengurangi mual dan muntah selain penggunaan aroma terapi lavender.

Uji statsitik Willcoxon diperoleh $\mathrm{p}$ value $(0,002)<\alpha(0,05)$ menunjukkan terdapat perbedaan signifikan setelah pemberian aroma terapi jahe. Hasil penelitian ini sesuai dengan Saswita (2010) yang mengatakan bahwa terjadi penurunan mual muntah setelah menggunakan aroma terapi jahe. Aroma terapi jahe yang diberikan pada ibu hamil trimester I efektif dalam mengurangi emesis gravidarum. Sedangkan untuk pemberian aroma terapi lavender didapatkan nilai $\mathrm{p}$ value $(0,000)<\alpha(0,05)$ yaitu perbedaan yang signifikan sesudah pemberian aroma terapi lavender. Nilai $p$ value pada hasil penelitian aroma terapi lavender lebih kecil dibandingkan aroma terapi jahe jadi dapat disimpulkan bahwa pemberian aroma terapi lavender lebih efektif dibandingkan dengan aroma terapi jahe yaitu sebesar 3,555 kali lebih efektif dibandingkan dengan aroma terapi jahe.

Berdasarkan hasil penelitian dan pembahasan disimpulkan bahwa aroma terapi lavender dan jahe mempunyai kandungan minyak atsiri untuk meningkatkan kesehatan fisik dan emosi. Lavender memiliki zat aktif berupa linalool dan linalyl acetate yang dapat berefek sebagai analgesik (Wolfgang \& Michaela, 2008).

\section{KESIMPULAN DAN SARAN}

Berdasarkan hasil penelitian tentang Efektivitas Pemberian Aromaterapi Lavender dan Jahe terhadap Penurunan Frekuensi Mual Muntah pada Ibu Hamil Trimester I diBPM Trucuk Klaten sebagai berikut :

1. Karakteristik responden sebagian besar adalah umur 20-35 tahun (71,9\%), pendidikan SMP $(53,1 \%)$, suku bangsa seluruhnya suku Jawa (100\%), pekerjaan ibu adalah tidak bekerja atau ibu rumah tangga $(81,3 \%)$.

2. Karakteristik mual muntah kurang dari 1 jam sebanyak (100\%) dan banyaknya 1-2 cangkir (100\%) 
3. Ada perbedaan yang signifikan antara mean intensitas derajat mual muntah sebelum dan sesudah pemberian aroma terapi jahe dengan nilai $\mathrm{p}$ value $=0,002(\alpha<0,05)$.

4. Ada perbedaan yang signifikan antara mean intensitas derajat mual muntah sebelum dan setelah pemberian aroma terapi lavender denga nilai $\mathrm{p}$ value $=$ $0,000(\alpha<0,05)$.

5. Aroma terapi lavender lebih efektif terhadap mual muntah $(8,50)$ dibandingkan dengan kelompok aroma terapi jahe $(6,50)$, sehingga dapat disimpulkan bahwa pemberian aroma terapi lavender lebih efektif dibandingkan aroma terapi jahe.

\section{SARAN}

1. Bagi ibu Hamil

Bada ibu hamil khususnya trimester I yang mengalami mual muntah gunakan aromaterapi lavender untuk mencegah dan mengatasinya.

2. Bagi Masyarakat

Aromaterapi Lavender dan Jahe sangat efektif mengurangi mual muntah pada wanita hamil trimester I ,maka manfaatkan tanaman yang ada dilingkungan kita

3. Bagi Bidan

Untuk memberikan asuhan kebidanan pada ibu hamil saat mual muntah dengan penggunaan Aromaterapi Lavender dan Jahe

4. Bagi BPM

Untuk meningkatkan program pelayanan asuhan kebidanan khususnya bagi wanita hamil trimester I tentang mual muntah pada sosialisasikan penggunaan Aromaterapi Lavender dan Jahe sebagai teraphy komplementernya

5. Bagi Institusi
Hasil penelitian sebagai bahan tambahan untuk pengetahuan dan informasi agar dapat mengembangkan penelitian selanjutnya dalam konteks yang berbeda.

\section{DAFTAR RUJUKAN}

Runiari, Nengah. 2010. Asuhan Keperawatan pada Klien dengan Hiperemesis gravidarum. Jakarta : Salemba Medika.

Saiffudin, dkk. 2009. Buku Acuan Nasional Pelayanan Kesehatan Maternal dan Neonatal. Jakarta : PT Bina pustaka Sarwono Prawirahardjo.

Setiawan dan Saryono. 2011. Metodelogi Penelitian KEBIDANAN DIII, DIV, S1 dan S2.Yogyakarta : Nuha Medika

Suririnah. 2008. Buku Pintar Kehamilan Dan Persalinan. Jakarta : Gramedia Pustaka Utama.

Ramadhan, Ahmad. 2013. Aneka Manfaat Ampuh Rimpang jahe Untuk Pengobatan. Yogyakarta : diandra Pustaka Indonesia.

Ratna, Dwi. 2010. Perawatan Ibu Hamil. Yogyakarta : Panji Pustaka.

Tiran, Denise. 2009. Mual Muntah Kehamilan. Jakarta : Buku Kedokteran ECG.

Vivian, D. 2007. Mengatasi MualMuntah dan Gangguan Lain Selama Kehamilan. Yogyakarta : Diglossia.

Wolfgang, Steflitsch \& Michaela. 2008. Aromatherapie. Springer. Vinna. 